\title{
Enhancement of Soybean (Glycine max L.) Productivity through Sowing Methods and Seed Rates in Telangana State
}

\author{
N. Swapna, Firdouz Shahana, T. Prabhakar Reddy, G. Praveen Kumar, M. Venkataiah
}

10.18805/LR-4424

\begin{abstract}
Background: With the unparalleled growth in area and production, soybean has established itself as a leading oilseed crop of India. The crop is mainly grown under rainfed conditions, and the distribution of rainfall plays an important role in yield realization. The changed landform management with broad-bed furrow seed drill is gaining popularity as the system helps in in situ moisture conservation and draining out excess rainwater. A field experiment was conducted at Regional Sugarcane and Rice Research Station, Rudrur. The yield advantage by adoption of broad-bed and furrow (BBF) method over flat bed was $7.06 \%$. Seed rate of $50 \mathrm{~kg}^{-1}$ recorded significantly higher mean seed yield of $2804 \mathrm{~kg} \mathrm{ha}^{-1}$ over 75, 38, $20 \mathrm{~kg} \mathrm{ha}^{-1}$. The total benefit from adoption of BBF method recorded net returns of $₹ 53,233 \mathrm{ha}^{-1}$ and $\mathrm{B}: C$ ratio of 2.58 over flatbed planting. Seed rate of $50 \mathrm{~kg} \mathrm{seed} \mathrm{ha}^{-1}$ recorded the highest net returns and $B: C$ ratio this was followed by $75 \mathrm{~kg} \mathrm{ha}^{-1}$ seed rate.

Methods: A field experiment was conducted for three years (2017-19) at Regional Sugarcane and Rice Research Station, Rudrur, situated at an altitude of $286.3 \mathrm{~m}$ above mean sea level at $18^{\circ} 49^{\prime} 41^{\prime \prime} \mathrm{N}$ latitude and $78^{\circ} 56^{\prime} 45^{\prime \prime} \mathrm{E}$ longitude. Indeterminate variety of soybean ASB 22 was selected. The experimental plots $\left(6 \mathrm{~m} \times 6 \mathrm{~m}=36 \mathrm{~m}^{2}\right)$ were laid out with split plot design with three replications. Main plot treatments were methods of planting: $M_{1}$ - Flat bed, $M_{2}$ - Broad bed and Furrow, and sub plot treatments were : seed rates; $\mathrm{S}_{1}-75 \mathrm{~kg} \mathrm{ha}^{-1}(30 \times 10 \mathrm{~cm}), \mathrm{S}_{2}-50 \mathrm{~kg} \mathrm{ha}^{-1}(30 \times 15 \mathrm{~cm}), \mathrm{S}_{3}-38 \mathrm{~kg} \mathrm{ha}^{-1}(30 \times 20 \mathrm{~cm}), \mathrm{S}_{4}-20 \mathrm{~kg} \mathrm{ha}^{-1}(30 \times 30 \mathrm{~cm})$.

Result: The grain yields, water productivity, harvest index and economics of soybeans under BBF method of planting (in-situ water conservation) and flatbed practices were studied. BBF method increased seasonal soil water storage by $5.37 \%, 5.78 \%$ and $6.20 \%$

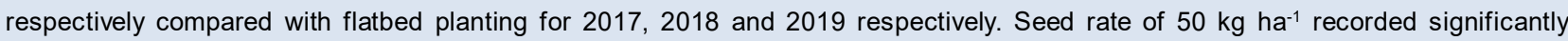
higher mean seed yield of $2804 \mathrm{~kg} \mathrm{ha}^{-1}$ over $75,38,20 \mathrm{~kg} \mathrm{ha}^{-1}$. The yield advantage by adopting seed rate of $50 \mathrm{~kg} \mathrm{ha}^{-1}$ was $16.08 \%$, $56.02 \%$ and $67.6 \%$ over 75,38 and $20 \mathrm{~kg} \mathrm{ha}^{-1}$ respectively. The total benefit from adoption of BBF method recorded net returns of ₹ $53,233 \mathrm{ha}^{-1}$ and $\mathrm{B}: \mathrm{C}$ ratio of 2.58 over flatbed planting. Seed rate of $50 \mathrm{~kg} \mathrm{ha}^{-1}$ recorded the highest net returns and $\mathrm{B}: \mathrm{C}$ ratio this was followed by $75 \mathrm{~kg} \mathrm{ha}^{-1}$. Broad bed and furrow method of planting and optimum seed rate in soybean will enhance the soybean productivity.
\end{abstract}

Key words: Broad-bed furrow, Harvest index, Soybean, Water conservation, Water productivity.

\section{INTRODUCTION}

Soybean [Glycine max (L.) Merrill] is an important crop with high protein and oil content. It is also used to make soya milk, tofu, soy nuts, etc. During 2019, it was grown on an area of $12.5 \mathrm{~m}$ ha in India with a production of 9.0 million tonnes and productivity of $942 \mathrm{~kg} \mathrm{ha}^{-1}$ (Anonymous, 2019). Furthermore, the furrow irrigated raised bed planting can save considerable amount of irrigation water and maximize water productivity (Bana et al., 2013; Temesgen et al., 2009). Also raised bed planting reduces seed rate and provides favourable environment for the growth and development of the soybean Kamara et al. (2014). The present investigation was therefore planned and conducted to study the growth, yield, economics and water productivity in soybean under different planting systems and different seed rates. Soybean have a smaller plant than most other grain crops and therefore have a smaller leaf area. A higher population is planted in order to intercept the maximum amount of sunlight. The ability of soybeans to branch out and produce more pods if there is enough space (phenotypic plasticity) explains the minor reaction of soybeans to different plant establishments (Khurshid et al., 2006; McHugh et al., 2017).
Department of Agronomy, Regional Sugarcane and Rice Research Station, Professor Jayashankar Telangana State Agricultural University, Rudrur-503 188, Nizamabad, Telangana, India.

Corresponding Author: N. Swapna, Department of Agronomy, Regional Sugarcane and Rice Research Station, Professor Jayashankar Telangana State Agricultural University, Rudrur-503 188, Nizamabad, Telangana, India. Email: swapna130290@gmail.com

How to cite this article: Swapna, N., Shahana, F., Reddy, T.P., Kumar, G.P. and Venkataiah, M. (2022). Enhancement of Soybean (Glycine max L.) Productivity Through Sowing Methods and Seed Rates in Telangana State. Legume Research. DOI: $10.18805 / L R-4424$

Submitted: $21-05-2020$ Accepted: 03-10-2020 Online: 12-01-2020

At a high plant establishment soybean plants will branch little, grow straight up and bear pods high above the ground. With a decrease in plant population, the inner-row space plants increases and the plant produces more lateral branches and pods Muthamil selvan et al. (2006). With very low plant populations some of the lateral branches and pods will be borne close to the ground. Although yield is retained, 
some of the lateral branches will lodge and bear pods on the ground, which reduces the harvestable yield. Recommendations for soybean establishment differ considerably and are complex due to the variation with respect to row widths, tillage practices and planting date differences. In normal kharif plantings in June, maximum yields are obtained with 25 to 50 plants per square meter. Adjustments in plant population must be made on the basis of the interaction between the production potential of the field, phenotypic plasticity and lodging of the cultivar on the basis of the proposed planting date. With early plant dates cultivars that tend to lodge or produce more lateral branches can be planted in a lower population Kumar et al. (2014). This is not the case for a late planting date. Soybeans that are planted early in fields with a high potential tend to grow very lushly. In such a case the plant population can be reduced. The above points to final plant populations of $1,80,000$ to $4,00,000$ plants per hectare. The higher populations in narrower rows are a result of more space in the rows and the interplant competition being less, which reduces the risk of thin stems and lodging. Accurate plant densities must be based on seed quantities per hectare and not on seed mass. Seed is sold according to weight, which makes it difficult to calculate seed requirements. The labels on the seed package are supposed to indicate the number of seeds per kilogram. This can then be used as a basis for calculating the relative quantity of seeds required. Most planter tables that are used for calibration also use relative data and the plant population should then be regarded as estimated. The only way in which planters can be calibrated accurately is to count the number of seeds that are placed over a specific distance by the planter. The seed sizes of different cultivars vary considerably. They will probably vary between 5,000 and 8,000 seeds per kilogram. Some cultivars tend to produce bigger seeds more than others, but the influence of environmental conditions during the grain-filling period have the biggest effect. He et al. (2016) and Sarkar (2005) reported that if drought or any other stress factor is experienced during the grain-filling period, the seeds will be smaller than normal. A good blossom period that leads to a lot of pods can also result in smaller seeds. The reverse can also be true. Very small seeds will not have an effect on the yield of the crop, provided the germination of the seed occurs correctly. It is not uncommon to get a large variation in seed sizes in one production unit.

\section{MATERIALS AND METHODS}

The field experiment was conducted during kharif session from 2017-2019 at Regional Sugarcane and Rice Research Station, Rudrur, situated at an altitude of 286.3. $\mathrm{m}$ above mean sea level (MSL) at $18^{\circ} 49^{\prime} 41^{\prime \prime} \mathrm{N}$ latitude and $78^{\circ} 56^{\prime}$ $45 " \mathrm{E}$ longitude. The experimental site is in Northern Telangana agro-climatic zone of Telangana state, India and experiences semiarid climate. The long-term (2017-2019) temperature and precipitation data of the site, collected from weather station (RS\&RRS, Rudrur, station), are illustrated in Table 1. The mean air temperature during the soybean growing season increased from $22.0^{\circ} \mathrm{C}$ in June to $28.4^{\circ} \mathrm{C}$ in October; the average temperature was $24.7^{\circ} \mathrm{C}$. Both the maximum and minimum temperatures were greater in August than in the other months (Table 1). The solar radiation varied from 11.1 to $17.0 \mathrm{MJ} m$ day over the crop period. The average relative humidity was $80.3 \%$. Total $814.4 \mathrm{~mm}$ rainfall, with the maximum quantity in second fortnight of August and first fortnight of September (during flowering and development stages of soybean), occurred during the crop season. No irrigation was applied to the crop except during 2018, one irrigation was given in the month of July due to mid-season drought. The reference evapotranspiration (ETo) was $5.6 \mathrm{~mm}$ day that fluctuated with the varying air temperature and solar radiation. Indeterminate variety of soybean ASB 22, was planted on June 26 in 2017, June 27, during 2018 and June 15 in 2019. The experimental plots (6 $\mathrm{m} \times 6 \mathrm{~m}=36 \mathrm{~m}^{2}$ ) were laid out with split plot design with three replications. Main plot treatments were methods of planting: $M_{1}$ - Flat bed, $M_{2}-$ Broad bed and Furrow, and sub plot treatments were : seed rates; $S_{1}-75 \mathrm{~kg} \mathrm{ha}^{-1}(30 \times 10 \mathrm{~cm})$, $\mathrm{S}_{2}-50 \mathrm{~kg} \mathrm{ha}^{-1}(30 \times 15 \mathrm{~cm}), \mathrm{S}_{3}-38 \mathrm{~kg} \mathrm{ha}^{-1}(30 \times 20 \mathrm{~cm}), \mathrm{S}_{4}-$ $20 \mathrm{~kg} \mathrm{ha}^{-1}(30 \times 30 \mathrm{~cm})$. This resulted in a total of 24 plots in the field. Each of the plots was separated by $0.5 \mathrm{~m}$ of transition zone while each of the replications was demarcated by a buffer zone of $1 \mathrm{~m}$ in between. Broad bed and furrows were laid by tractor drawn broad bed and furrow former. Each broad bed was constructed with $120 \mathrm{~cm}$ width and $6 \mathrm{~m}$ length and $30 \mathrm{~cm}$ of furrow in between the broad beds which act as dead furrow used for storage of moisture.

Undisturbed soil samples were collected from the root zone of soybean: $0-10,10-20$ and $20-30 \mathrm{~cm}$ soil proûle under each treatment by using core samplers. Texturally, the soil in the study site was heavy black soil in the $0-30 \mathrm{~cm}$ soil layer. The bulk density of the soil were determined by

Table 1: Weather data from 2017 to 2019.

\begin{tabular}{|c|c|c|c|c|c|c|c|c|}
\hline \multirow{2}{*}{ Period } & \multirow{2}{*}{$\begin{array}{c}\text { Rainfall } \\
(\mathrm{mm})\end{array}$} & \multicolumn{3}{|c|}{ Temperature $\left({ }^{\circ} \mathrm{C}\right)$} & \multicolumn{3}{|c|}{$\mathrm{RH}(\%)$} & \multirow{2}{*}{$\begin{array}{c}\mathrm{ET}^{\circ} \\
\left(\mathrm{mm} \text { day }^{-1}\right)\end{array}$} \\
\hline & & Max & Min & Mean & Max & Min & Mean & \\
\hline June & 86.80 & 27.80 & 37.60 & 32.7 & 96.57 & 85.70 & 91.13 & 4.83 \\
\hline July & 150.04 & 25.45 & 33.37 & 29.41 & 96.16 & 87.65 & 91.95 & 3.47 \\
\hline August & 126.45 & 25.03 & 30.87 & 27.95 & 95.35 & 86.97 & 91.16 & 3.02 \\
\hline September & 301.12 & 24.60 & 30.80 & 27.7 & 95.13 & 83.80 & 89.46 & 4.23 \\
\hline October & 13.62 & 22.97 & 30.77 & 26.87 & 94.61 & 76.39 & 85.5 & 4.43 \\
\hline
\end{tabular}


drying the samples in oven at $105^{\circ} \mathrm{C}$ for $24 \mathrm{~h}$ and recorded 1.02, 1.0, 0.98 for 2017,2018 and 2019 respectively. Soil organic matter (OM) content was determined by ignition method in which weight loss of the soil samples on ignition was measured. The duration of the growth stages was determined using the procedures in Burton (1987). Plant heights were measured using a meter rule. SWS at vegetative (VE - V2) and reproductive stages namely: flowering ( $F L)$, pod initiation (PI), seed filling (SF) and maturity (MT) were determined by using Eq. (1) (He et al., 2016; Liu et al., 2013).

$$
\mathrm{SWS}=\sum \theta_{1 / 4} \times Z \mathrm{i}_{1 / 4} \times \mathrm{n}
$$

Where,

$\mathrm{SW}=$ total soil water storage $(\mathrm{mm})$,

$\theta^{1 / 4}$ moisture content for soil root zone,

$\mathrm{Zi}^{1} / 4$ soil layer $(\mathrm{mm}), \mathrm{n}^{1} / 4$ number of soil layers.

Flowering and pod initiation lasted for 20 and 6 days, while seed filling and maturity took 32 and 18 days, respectively in 2017 . The comparative length of the stages in 2018 and 19 were 16, 7, 37 and 18 days. The total SWS was determined for the upper $30 \mathrm{~cm}$ depth where more than $90 \%$ of the active roots were located ( $\mathrm{Li}$ et al., 2007) by adding the SWS from 0 to $10,10-20$ and $20-30 \mathrm{~cm}$ at the stated stage. After maturity on September $18^{\text {th }}, 2017$ at 117 days after planting (DAP), October $13^{\text {th }}, 2018$ at 120 DAP and October $13^{\text {th }}, 2019$ at 123 DAP. Plants within $36 \mathrm{~m}^{2}$ at the central rows were harvested, threshed and grain yields per hectare were estimated. Above ground biomass at harvest time was taken from $30 \mathrm{~m}^{2}$ (120 plants) from three replicates, oven dried at $70^{\circ} \mathrm{C}$ for $24 \mathrm{~h}$ and dry above ground biomass (DAB) per unit area was estimated. Harvest index $(\mathrm{HI})$ was determined from the ratio of the harvested grain yield to DAB.

\section{RESULTS AND DISCUSSION}

\section{Plant height (cm)}

Plant height differed significantly between planting methods and seed rates. Broad bed and furrow method of planting recorded significantly superior plant height over flatbed method of planting in all three seasons. Among the seed rates, $50 \mathrm{~kg} \mathrm{ha}^{-1}$ recorded significantly highest plant height over 75, 38 and $15 \mathrm{~kg}$ seed ha-1. This might be due to in-situ conservation of moisture in furrows, proper aeration and optimum plant population with less inter and intra competition for light, nutrition and water led to highest plant height (Liu et al., 2013, Li et al., 2007). This was followed by 38 and $15 \mathrm{~kg}$ seed rate ha- ${ }^{-1}$ on both BBF and flat bed. Lowest height recorded in with $75 \mathrm{~kg}$ seed ha-1. Alliaume et al., 2014 reported that higher seed rate leads to lanky vegetative growth in soy bean which resulted in higher infestation of defoliator at vegetative stage followed by pod blight at pod initiation stage Table 2 .

\section{Number of pods plant ${ }^{-1}$}

Broad bed and furrow method of planting recorded the highest number of pods per plant over flat bed method of sowing. Seed rate of $50 \mathrm{~kg} \mathrm{ha}^{-1}$ recorded significantly higher number of pods per, plant which was followed by $38 \mathrm{~kg} \mathrm{ha}$ ${ }^{1}$ and was at par with $20 \mathrm{~kg} \mathrm{ha}^{-1}$ (Table 2). Wang et al., (2015) reported that optimum seed rate with critical requirement of soil moisture is necessary for production of higher pods.

\section{Seed yield $\left(\mathrm{kg} \mathrm{ha}^{-1}\right)$}

Planting methods and seed rates significantly influenced seed yield however there was no interaction between the planting methods and seed rates. Broad bed furrow method recorded significantly superior seed yield over flatbed method of planting. The yield advantage by adoption of broad-bed and furrow (BBF) method over flatbed was $7.06 \%$. Seed rate of $50 \mathrm{~kg} \mathrm{ha}^{-1}$ recorded significantly higher mean seed yield of $2804 \mathrm{~kg} \mathrm{ha}^{-1}$ over flat $75,38,20 \mathrm{~kg}$ seed ha-1 (Table 2.). The yield advantage by adopting $50 \mathrm{~kg}$ seed ha-1 was $16.08 \%, 56.02 \%$ and $67.6 \%$ over 75,38 and $20 \mathrm{~kg}$ seed ha $^{-1}$ respectively. Li et al., 2001 reported that BBF system (on lands with slope less than $2 \%$ ) in comparison to flatbed system induced good root development, good nodulation, better crop growth, better pod filling and early maturity in groundnut, besides considerable saving of time and cost of cultivation cost of cultivation. $20 \mathrm{~kg}$ seed rate per hectare recorded the lowest yield in both flat and broad bed method of planting.

Table 2: Effect of planting methods and seed rate on plant height, number of pods plant $^{-1}$ and yield of soy bean.

\begin{tabular}{|c|c|c|c|c|c|c|c|c|c|}
\hline \multirow{2}{*}{ Treatment } & \multicolumn{3}{|c|}{ Plant height $(\mathrm{cm})$} & \multicolumn{3}{|c|}{ Number of pods plant ${ }^{-1}$} & \multicolumn{3}{|c|}{ Seed yield $\left(\mathrm{kg} \mathrm{ha}^{-1}\right)$} \\
\hline & Flat bed & BBF & Mean & Flat bed & BBF & Mean & Flat bed & BBF & Mean \\
\hline $\mathrm{S}_{1}\left(75 \mathrm{~kg} \mathrm{ha}^{-1}\right)$ & 48.88 & 46.13 & 47.50 & 101 & 118 & 109 & 2259 & 2448 & 2353 \\
\hline $\mathrm{S}_{2}\left(50 \mathrm{~kg} \mathrm{ha}^{-1}\right)$ & 49.56 & 51.62 & 50.59 & 136 & 176 & 156 & 2649 & 2959 & 2804 \\
\hline $\mathrm{S}_{3}\left(38 \mathrm{~kg} \mathrm{ha}^{-1}\right)$ & 49.05 & 48.88 & 48.96 & 119 & 128 & 129 & 1251 & 1214 & 1233 \\
\hline \multirow[t]{3}{*}{$\mathrm{S}_{4}\left(20 \mathrm{~kg} \mathrm{ha}^{-1}\right)$} & 49.09 & 48.88 & 48.98 & 129 & 143 & 132 & 868 & 943 & 905 \\
\hline & 48.88 & 49.14 & & 129 & 134 & & 1757 & 1891 & \\
\hline & $\begin{array}{l}\text { Planting } \\
\text { method }\end{array}$ & $\begin{array}{c}\text { Seed } \\
\text { rate }\end{array}$ & $\begin{array}{l}\text { Planting } \\
\text { method } \\
\text { X Seed } \\
\text { rate }\end{array}$ & $\begin{array}{l}\text { Planting } \\
\text { method }\end{array}$ & $\begin{array}{c}\text { Seed } \\
\text { rate }\end{array}$ & $\begin{array}{l}\text { Planting } \\
\text { method } \\
\text { X Seed } \\
\text { rate }\end{array}$ & $\begin{array}{r}\text { Planting } \\
\text { method }\end{array}$ & $\begin{array}{c}\text { Seed } \\
\text { rate }\end{array}$ & $\begin{array}{r}\text { Planting } \\
\text { method } \\
\text { X Seed } \\
\text { rate }\end{array}$ \\
\hline SEm ( \pm ) & 0.04 & 0.24 & NS & 1.5 & 9.9 & NS & 18.49 & 71.28 & NS \\
\hline C.D. $(p=0.05)$ & 0.27 & 0.76 & NS & 4.02 & 31.10 & NS & 121.2 & 222.1 & NS \\
\hline
\end{tabular}


Table 3: Soil water consumption, water productivity and harvest index of soybean (mean from 2017-2019).

\begin{tabular}{lccc}
\hline Treatments & $\begin{array}{c}\text { Soil water consumption } \\
(\mathrm{mm})\end{array}$ & $\begin{array}{c}\text { Water productivity } \\
\left(\mathrm{kg} \mathrm{ha}^{-1} \mathrm{~mm}^{-1}\right)\end{array}$ & $\begin{array}{c}\text { Harvest index } \\
(\%)\end{array}$ \\
\hline Factor A (Soybean Planting Method) & & & 7.15 \\
$\mathrm{M}_{1}$ (Flat bed) & 314.56 & 8.06 & 52.47 \\
$\mathrm{M}_{2}$ (Broad Bed Furrow (BBF)) & 456.23 & 0.30 & 58.98 \\
SEm $( \pm)$ & 0.99 & 1.12 & 1.82 \\
CD $(p=0.05)$ & 6.04 & & 3.98 \\
Factor B (Seed rate) & & 6.12 & 50.2 \\
$\mathrm{~S}_{1}\left(75 \mathrm{~kg} \mathrm{ha}^{-1}\right)$ & 396.45 & 7.95 & 56.42 \\
$\mathrm{~S}_{2}\left(50 \mathrm{~kg} \mathrm{ha}^{-1}\right)$ & 404.23 & 5.21 & 44.23 \\
$\mathrm{~S}_{3}\left(38 \mathrm{~kg} \mathrm{ha}^{-1}\right)$ & 386.23 & 4.40 & 41.67 \\
$\mathrm{~S}_{4}\left(20 \mathrm{~kg} \mathrm{ha}^{-1}\right)$ & 398.56 & 0.34 & 2.01 \\
$\mathrm{SEm}( \pm)$ & 13.93 & 1.62 & 5.62 \\
CD $(p=0.05)$ & $\mathrm{NS}$ & 1.58 & $\mathrm{NS}$ \\
Interaction $(\mathrm{v}$ x s) & $\mathrm{NS}$ & & \\
\hline
\end{tabular}

Table 4: Economics of soybean planting methods as influenced by varied seed rate (mean from 2017-2019).

\begin{tabular}{|c|c|c|c|c|}
\hline Treatments & Gross returns ₹ ha $^{-1}$ & Cost of cultivation $₹ \mathrm{ha}^{-1}$ & Net returns ₹ ha $^{-1}$ & $\mathrm{~B}: \mathrm{C}$ ratio \\
\hline \multicolumn{5}{|c|}{ Factor A (Soybean Planting Method) } \\
\hline $\mathrm{M}_{1}$ (Flat bed $)$ & 59,945 & 32,375 & 27,570 & 1.85 \\
\hline $\mathrm{M}_{2}$ (Broad Bed Furrow (BBF) & 66,841 & 30,366 & 36,475 & 2.20 \\
\hline SEm $( \pm)$ & 620.4 & 456.2 & 598.2 & 0.12 \\
\hline$C D(p=0.05)$ & 1969 & 1256 & 1563 & 0.26 \\
\hline \multicolumn{5}{|l|}{ Factor B ( Seed rate) } \\
\hline $\mathrm{S}_{1}\left(75 \mathrm{~kg} \mathrm{ha}^{-1}\right)$ & 86,106 & 35,671 & 50.435 & 2.41 \\
\hline $\mathrm{S}_{2}\left(50 \mathrm{~kg} \mathrm{ha}^{-1}\right)$ & 87,915 & 32,682 & 55,233 & 2.69 \\
\hline $\mathrm{S}_{3}\left(38 \mathrm{~kg} \mathrm{ha}{ }^{-1}\right)$ & 44,034 & 29,512 & 14,522 & 1.49 \\
\hline $\mathrm{S}_{4}\left(20 \mathrm{~kg} \mathrm{ha}^{-1}\right)$ & 31,610 & 23,976 & 7,634 & 1.31 \\
\hline $\operatorname{SEm}( \pm)$ & 662.3 & 432.5 & 562.3 & 0.09 \\
\hline$C D(p=0.05)$ & 1230 & 1162 & 1501 & 0.25 \\
\hline Interaction ( $\mathrm{v} \times \mathrm{s})$ & NS & NS & NS & NS \\
\hline
\end{tabular}

\section{Soil water Consumption $(\mathrm{mm})$}

The soil-moisture content in the soybean plots under the BBF method fluctuated with rainfall and air temperature over the growing season, with the flatbed method exhibiting a greater fluctuation of soil-moisture content. The soil moisture content was the maximum in July due to greater rainfall, but decreased in August due to limited rainfall and greater temperature and increased during the months of September and October in BBF method. The daily soil-moisture content at $5 \mathrm{~cm}$ depth was the maximum under BBF method and minimum in the flat bed method (Table 3 ).

\section{Water productivity $\left(\mathrm{kg} \mathrm{ha}^{-1} \mathrm{~mm}^{-1}\right)$ and harvest index (\%)}

Water productivity and harvest index were significantly the highest in broad bed and furrow method as it act as both water conservation channel and for draining of excess water (Table 3). $50 \mathrm{~kg} \mathrm{ha}^{-1}$ seed rate recorded significantly the highest water productivity followed by $75 \mathrm{~kg} \mathrm{ha}^{-1}$ seed rate. Adeboye et al. (2015); Qin et al. (2015) and Nuti et al. (2009) reported that broad bed and furrow registered high water productivity due to dead furrows in between rows.

\section{Economics}

Among planting methods, Broad bed and furrow method recorded the highest net returns and $\mathrm{B}: \mathrm{C}$ ratio over flatbed method of planting. Seed rate of $50 \mathrm{~kg} \mathrm{ha}^{-1}$ recorded the highest net returns and $B: C$ ratio this was followed by $75 \mathrm{~kg}$ $\mathrm{ha}^{-1}$ seed rate (Table 4). Broad bed and furrow maker sow seed and apply fertilizer at same time which resulted in low cost of cultivation besides saving time (Sarkar and Singh 2006).

\section{CONCLUSION}

The grain yields, water productivity, harvest index and economics of soybeans under Broad-bed and furrow method of planting (in-situ water conservation) and the conventional practices were studied for three consecutive rainy seasons. broad-bed and furrow method of planting increased seasonal soil water storage by $5.37 \%, 5.78 \%$ and $6.20 \%$ respectively compared with conventional practice of planting without water conservation. The yield advantage by adoption of broad-bed and furrow (BBF) method over flat bed was $7.06 \%$. Seed rate of $50 \mathrm{~kg}$ seed $\mathrm{ha}^{-1}$ recorded significantly 
higher mean seed yield of $2804 \mathrm{~kg}$ seed ha-1 over 75,38 , $20 \mathrm{~kg}$ seed $\mathrm{ha}^{-1}$. The yield advantage by adopting $50 \mathrm{~kg}$ seed $\mathrm{ha}^{-1}$ was $16.08 \%, 56.02 \%$ and $67.6 \%$ over 75,38 and $20 \mathrm{~kg}$ seed $\mathrm{ha}^{-1}$ respectively. The results analysis revealed that total benefit from adoption of BBF for the year 20172019 have been recorded net returns of $₹ 53,233$ ha $^{-1}$ and $\mathrm{B}: \mathrm{C}$ ratio of 2.58 over flat bed of planting. Seed rate of 50 $\mathrm{kg}$ seed $\mathrm{ha}^{-1}$ recorded the highest net returns and $\mathrm{B}: \mathrm{C}$ ratio this was followed by $75 \mathrm{~kg} \mathrm{ha}^{-1}$ seed rate. Broad bed and furrow method of planting and optimum seed rate in soybean will enhance the soybean productivity.

\section{REFERENCES}

Adeboye, O.B., Schultz, B., Adekalu, K. O., Prasad, K. (2015). Crop water productivity and economic evaluation of drip-irrigated soybeans [Glyxine max (L.) Merr.]. Agriculture and Food Secction. 4(1): 1-13.

Alliaume, F., Rossing, W.A.H., Tittonell, P., Jorge, G., Dogliotti, S. (2014). Reduced tillage and cover crops improve water capture and reduce erosion of fine textured soils in raised bed tomato systems. Agricultural Ecology and Environment. 183: $127-137$.

Anonymous, (2019). Agricultural statistics at a glance. DAC, Government of India.

Bana, S., Prijono, S., Ariffin, K., Marno, S. (2013). The effect of soil management on the availability of soil moisture and maize production in dryland. International Journal of Agriculture and Forestry. 3(3): 77-85.

Burton, J.W. (1987). Quantitative genetics: results relevant to soybean breeding. In Soybeans: Improvement, Production and Use. Agronomy. 16(2): 211-247.

He, G., Wang, Z., Li, F., Dai, J., Li, Q., Alhi, S.S. (2016). Soil water storage and winter wheat productivity affected by soil surface management and precipitation in dryland of the Loess Plateau, China. Agricultural Water Management. 171: $1-9$.

Kamara, A.Y., Ewansiha, S.U., Boahen, S., Tofa, A.I. (2014). Agronomic response of soybean varieties to plant population in the Guinea Savannas of Nigeria. Agronomy Journal. 106(3): 1051-1059.

Khurshid, K., Iqbal, M., Arif, M.S. and Nawaz, A. (2006). Effect of tillage and mulch on soil physical properties and growth of maize. International Journal of Agriculture and Biology. 8(5): 593-596.

Kumar, M., Singh, K.P., Srinivas, K. and Reddy, K.S. (2014). In-situ water conservation in upland paddy field to improve productivity in north-west Himalayan region of India. Paddy and Water Environment. 12(1): 181-191.
Li, Y.S., Wu, L.H., Zhao, L.M., Lu, X.H., Fan, Q.L. and Zhang, F.S. (2007). Influence of continuous plastic film mulching on yield, water use efficiency and soil properties of rice fields under non-flooding condition. Soil and Tillage Research. 93: $370-378$.

Li, X.Y., Gong, J.D., Gao, Q.Z. and Li, F.R. (2001). Incorporation of ridge and furrow method of rainfall harvesting with mulching for crop production under semiarid conditions. Agricultuarl Water Management. 50(3): 173-183.

Liu, S., Zhang, X.Y., Yang, J. and Drury, C.F. (2013). Effect of conservation and conventional tillage on soil water storage, water use efficiency and productivity of corn and soybean in Northeast China. Acta Agriculturae Scandinavica, Section B-Soil and Plant Science. 63(5): 383-394.

McHugh, O.V., Steenhuis, T.S., Berihun, A. and Fernandes, E.C.M. (2017). Performance of in situ rainwater conservation tillage techniques on dry spell mitigation and erosion control in the drought-prone North Wello zone of the Ethiopian highlands. Soil and Tillage Research. 97(1): 19-36.

Muthamil selvan, M., Manian, R. and Kathirvel, K. (2006). In-situ moisture conservation techniques in dry farming - A review. Agricultural Review. 27(1): 67-72.

Nuti, R.C., Lamb, M.C., Sorensen, R.B. and Truman, C.C. (2009). Agronomic and economic response to furrow diking tillage in irrigated and non-irrigated cotton (Gossypium hirsutum L.). Agricultural Water Management. 96(7): 1078-1084.

Qin, W., Wang, D., Xisheng, G., Taiming, Y. and Oene, O. (2015). Productivity and sustainability of rainfed wheat-soybean system in the North China Plain: results from a longterm experiment and crop modelling. Scientific Reports. 5: $1-16$.

Sarkar, S. (2005). Evapotranspiration and yield response of wheat to irrigation frequencies and fertilizer levels. Journal of the Indian Society of Soil Science. 53: 54-59.

Sarkar, S. and Singh, S.R. (2006). Irrigation, tillage and mulching effects on soybean yield and water productivity in relation to soil texture. Agricultural Water Management. 98(4): 563-568

Temesgen, M., Hoogmoed, W.B., Rockstrom, J. and Savenije, H.H.G. (2009). Conservation tillage implements and systems for smallholder farmers in semi-arid Ethiopia. Soil and Tillage Research. 104(1): 85-191.

Wang, Z., Zhao, X., Wu, P. and Chen, X. (2015). Effects of water limitation on yield advantage and water use in wheat (Triticum aestivum L.) maize (Zea mays L.) strip intercropping. European Journal of Agronomy. 71: 149-159. 